\title{
"Lost Hero of the Past": Ruin, Wound, and the Failure of Idealism in the Poetry of James Clarence Mangan
}

\section{Ciara Hogan}

\section{(2) OpenEdition \\ Journals}

Electronic version

URL: http://journals.openedition.org/etudesirlandaises/1834

DOI: 10.4000/etudesirlandaises. 1834

ISSN: 2259-8863

\section{Publisher}

Presses universitaires de Rennes

\section{Printed version}

Date of publication: 30 June 2010

Number of pages: 131-146

ISSN: 0183-973X

\section{Electronic reference}

Ciara Hogan, " "Lost Hero of the Past": Ruin, Wound, and the Failure of Idealism in the Poetry of James Clarence Mangan », Études irlandaises [Online], 35-1 | 2010, Online since 30 September 2012, connection on 20 April 2019. URL : http://journals.openedition.org/etudesirlandaises/1834 ; DOI 10.4000/etudesirlandaises.1834

This text was automatically generated on 20 April 2019.

(c) Presses universitaires de Rennes 


\title{
"Lost Hero of the Past": Ruin, Wound, and the Failure of Idealism in the Poetry of James Clarence Mangan
}

\author{
Ciara Hogan
}

\section{James Clarence Mangan and the Critical Canon}

1 From early contributions by John Mitchel, W. B. Yeats, and James Joyce to contemporary studies by Robert Welsh, Ellen Shannon-Mangan, and David Lloyd the field of Mangan studies has been dominated by debates about canonicity and the extent to which Mangan can be said to lie inside the canonical boundaries of Irish cultural nationalism. A predominantly middle-brow movement which dominated Irish letters in the first half of the nineteenth century, cultural nationalism was premised on joint principles of cultural unity, spiritual essence, and national identity, common to all European romantic and nationalist movements. In Ireland the ideology of respectable nationalism established itself around Thomas Davis and the Young Irelanders, whose Nation newspaper became the axis of romantic-nationalist publishing in the country. Its literature provided a unifying grammar for their governing ideology: evoking the authentic and timeless spirit of the Irish nation, it sought to conquer "sectarian and social differences" in Irish society, and to nationalise consciousness around the ideal of a discreet and harmonious cultural identity ${ }^{1}$. Although based on an ideal, rather than a material or economic, definition of Irish culture, the Young-Ireland ethos not altogether twee. Its schema, linking "language, culture and national destiny", marked out a serious "political and cultural project ${ }^{2}$ "; and its literature aimed to be both mentally bracing and socially improving. "Vibrant", in Arthur Griffith's words, "with manliness and passion", it was "written deliberately to reawaken and strengthen the national spirit and inflame the national mind". Against this earnest, ethical patriotism, then, press Mangan's familiar problems with ideological commitment, ethical debility, and the endurance of faith. And discussions of Mangan's intersection with cultural nationalism typically focus on his ambiguous submission to its 
idealist agenda, as well as his willingness to deploy (reliably) key signifiers of Irish identity in a universalising aesthetic.

The most significant aspects of the debate have crystallised in or around the discussion laid out by David Lloyd in Nationalism and Minor Literature. Lloyd's Mangan is antiestablishment. He defines the poet according to his "recalcitrance to the demands of nationalist [...] aesthetics" to construct "a major writing [...] whose function is to produce identity". This recalcitrance manifests itself in Mangan's deliberate non-conformity with nationalist poetics. Styles and subjects are so various in Mangan; postures so multiple; parody so commonplace; irony and ambiguity such standard structural features of the verse, that any single interpretation of the poet in terms of a romantic-national school is unsustainable. By refusing to fix himself in any one subject position, Lloyd argues, Mangan rejects the privileged subjectivity of the poet of literary romanticism. By refusing to merge his voice with that of the "nation", Mangan resists assimilation into the cultural-nationalist canon.

3 While Lloyd's larger point that Mangan challenges the homogeneity of literary nationalism is crucial, it may, however, be overstated in terms of the poet's resistance to aesthetic or political labels. For Mangan variously displays a comically incongruous and unambiguously poignant relationship to romantic canons, nationalist politics, and romantic poet types. As Seán Ryder points out, Mangan's Catholic lower middle-class background meant that nationalism was part of his cultural grammar; and the poet has, by turn, been linked to the literatures of Catholic and working-class nationalism, as well as to that of Davis and Young Ireland ${ }^{5}$. Patricia Coughlan, meanwhile, has traced the influence of English romanticism on Mangan's work, finding that many of his best poems on heroic themes (Irish and otherwise) are spoken "as if" voiced by a Byronic poet type. Their mobilisation may involve "a sense of their ridiculousness when brought into relation with [modern...] life", but Mangan's work nonetheless evidences a "perpetually recurring contest between the quotidian and the transcendent" in romantic poetics ${ }^{6}$.

The same strain between the quotidian and the transcendent characterises Mangan's bearing towards romantic nationalism and the romantic bardic role. Ideally, and ideologically, the bard of nineteenth-century nationalism functioned as the spokesman of culturally unambiguous experience, often figured as the mythic (primordial and suprahistorical) spirit of the nation. However, in Mangan a consciousness of material everyday contexts disrupts the possibility of any correspondence with the high-romantic ideal or any full merging with cultural nationalism; the role of romantic bard is problematic for him in consequence. As I argue at length elsewhere, Mangan's attitude to ideals of cultural authority was strongly inflected by his economic and class experience; and in the poetry a class-based scepticism leads directly to the questioning of authority and the utility of poetry in real life. Mangan's lower-class experience bred a degree of cynicism about the material advantages a national literature, or indeed national sovereignty, could offer a man at his end of the social spectrum; as such, they deeply affected his ability to construct himself as a poet in the largely bourgeois tradition of the Nation authors ${ }^{7}$.

Nevertheless, while Mangan is critical of received platitudes about the transcendent romantic imagination and the general benefits of Young-Ireland nationalism, his writing continues to give evidence of a later-romantic poet with nationalist sympathies. The problem that remains in Mangan studies, then, lies not in rejecting but in rebalancing Mangan's uneasy fit in romantic-nationalist canons. This article seeks to do just that, in an analysis of the poetry written in the 1840s, the period that witnessed the ascendancy 
of the cultural-nationalist movement as well as its imminent collapse as it coincided with the Great Famine of 1845-1849.

6 My aim is to locate Mangan's writing with respect to larger currents of thought governing cultural discourse at mid-century. I will be paying particular attention to a literature of cultural improvement, common across the Victorian period, whose themes of perfectionism and exemplarity were a defining, if under-explored, influence on the culture-building discourse of Irish nationalists. If Mangan's attraction to romantic nationalism can be explained by the movement's intellectual and cultural authority, his discomfort with the perfectionist tradition can similarly be traced to his social and class experience, where a healthy suspicion of improving discourse was active and commonplace. The following pages explore Mangan's personal engagement with this perfectionist tradition, then, teasing out evidence of his uneasy but visible attachment to national culture-building, and analysing its ramifications for the mainstream nationalist canon. Throughout, my analysis is guided by the view that Mangan's uneven relation with romantic nationalism is representative in terms of his class and cultural background: the overwhelming occurrence of tropes of ruin and rupture in the verse formalise his sense of social dislocation, in my view. This paper will also look at moments of ruin, wounding, and formal rupture in Mangan, reading them as a means of figuring his philosophical breakage from the governing ideology of the nationalist establishment. A final word: although there will be much in the way of echoing and overlapping, my discussion does not absolutely seek to bond stray elements of Mangan, so much as to weigh them up in their incongruous relationship with each other. In tracing the path of Mangan's own irresolute nationalism, the following essay will also, therefore, contain much in the way of necessary qualification, contradiction, and questioning.

\section{"I Dreamed in my Folly": Mangan's Faltering Perfectionism}

7 As Seán Ryder points out, in spite of his waywardness, Mangan does in fact frequently voice a sense of "artistic responsibility". His work regularly presents poetry in terms of its "deep moral purpose" to "elevate" the reader's "spirit". Many of the poems from the end of Mangan's life address readers in terms that exhort, entreat, and advise. "A Voice of Encouragement" (1848), "For Soul and Country" (1849), "Bear Up" (1849) - all Famine poems - seek to bolster Irish culture in a time of national crisis. "The Nameless One" (1849) speaks in terms of a more general philosophy. There, Mangan explicitly bequeaths his song "to after-ages" to "tell how... / He would have taught Men, from Wisdom's pages, / The way to live". Meanwhile his Autobiography seeks to present his own life to afterages as a cautionary moral case:

At a very early period in my life I became impressed by the conviction that it is the imperative duty of every man who has sinned deeply and suffered deeply to place upon record some memorial of his wretched experience for the benefit of his fellow creatures, and by way of a beacon to them, to avoid, in their voyage of existence, the rocks and shoals upon which his own peace of soul has undergone shipwreck ${ }^{10}$.

The modes of ethical presentation visible in these last two texts particularly, correspond with a literature of responsibility and moral purpose widespread in the Victorian period. More specifically, they conform to a mode of Victorian perfectionist writing, visible in the 
ideological hero-worship of British as well as Irish authors, and concretised in the literature of moral exemplars.

9 The concept of the cultural exemplar arose in Germany and England around 1800, and its influence is felt in the Irish cultural-nationalist schools in which Mangan moved. In all contexts the exemplar was a crucial figure in discourses that sought to construct, codify, and perfect culture ${ }^{11}$. Exemplarity of an ethical or cultural-specific kind was central to the construction of the romantic-nationalist canon. The exemplary men who peopled YoungIreland ballads played a central role in the formation of cultural-nationalist philosophy as ideal or aspirational types that putatively embodied what Davis might call the spirit of the nation ${ }^{12}$. The ballad itself, which tends to raise its content to a universal level, was the ideal medium for acculturation. Within cultural-nationalist ballads, verse narratives functioned as representative anecdotes, from which an idealised history of the country could be constructed. They instanced cases of national heroism from which an ideal, heroic, national self could be learned. In this context cultural perfectionism comes to be understood as the achievement of a new self through the contemplation of exemplary others who, in demonstrating excellence, inspire it. Thus, just as the ideal Young-Ireland poet should merge his identity with that of the nation by writing within universal ballad forms, the average reader should merge his moral identity with that of the ballad hero by reproducing spirited nationalism in everyday contexts.

While Mangan did not buy wholesale into the myth of Irish nationality, considerations of ethical exemplarity emerge strongly in his verse. He shows himself to be attentive to the function of ancient heroes as exemplary types from whom an ethical self could be constructed; and he registers his own relationship to them through pedestrian patterns of engagement and imitation, as well as by donning the mantle of bardic exemplar, the traditional mouthpiece for cultural-nationalist values. Hence Mangan's formal contribution to the canons of cultural-nationalist poetry, in texts that valorise the heroism of patriot endeavour and celebrate a catalogue of exemplars of Irish nationalism. "The Lamentation of Mac Liag for Kincora" (1841) commemorates Brian Boru, his blood descendants, and his martial sept, the "Dalcassians of the Golden Swords". The "Testament of Cathaeir Mor" (1846) and "A Vision of Connaught" (1846) celebrate Cáhal Mór, king of Connaught, of "the Wine-red Hand". The "Elegy on the Tironian and Tirconnellian Princes" (1840) laments the passing of the O'Donnells and the O'Neills. "O'Hussey's Ode to the Maguire" (1846) honours the adversity endured by Hugh Maguire in the 1600-1601 Munster campaigns with Hugh O'Neill.

11 Robert Welsh finds the "surging waves of energy and excitement" conveyed in these poems an index of their importance for Mangan: "what was Irish, was, in some sense or other, his by right of inheritance. [...] Because these poems [...] were somehow his, he may have felt that through them he would escape from himself into knowledge of himself, as part of some kind of national being" ${ }^{13}$. Yet, in spite of a demonstrable attraction to mythic heroes of the national imaginary, Mangan is also demonstrably inconstant in his attachments to them. His Irish poems are haunted by shades of alienation and the national bard is often presented as a figure in pained isolation. Moreover, such accounts of exemplary Irishmen as these poems provide are rarely offered in a manner that promises any national unity of vision, or, indeed, any real access to moral or historical aspiration. As nearly all commentators have pointed out, the heroic times the poems evoke have passed, and their visions of exemplary heroism are therefore either past utterly or spectrally alive in an unstable, visionary present. 

that Nuala O'Donnell must mourn Hugh O'Neill and Rury and Cathbar O'Donnell alone and in exile - her solitude is heightened by an ideal, imaginary home-scene wherein "one wail would rise from Crucahan's walls / To Tara's Hill". At home, the bards themselves are sickening and ailing in their inherited contexts. In the "Lament Over the Ruins of the Abbey of Teach Molaga" (1846) the poet closes noting, "If change is here, / Is it not o'er the land? - Is it not too in me? / Yes I am changed even more than what I see". Change leads to foolishness and doubt, doubt in one's choice of exemplar and doubt in one's ability to judge. The "Teach Mologa" poet can only say, at last, "I thought" (my emphasis) that "Piety and Peace; Virtue and Truth" were housed in the saint's abbey, or embodied in the brotherhood gathered there. When Mangan reanimates the historical bard, he habitually animates a world of impoverished isolation. "Culture" in this context is one of loss and fragmentation, implying a fragmenting or lost system of idealised belief. The spokesman of national culture appears a faltering orator, meanwhile, possessed of doubtful authority and insight. In Mangan's idiosyncratic version of "Gile na Gile", "The Vision of Egan O'Reilly" (1849), the poet dreams "in my folly" (my emphasis) of a "glorious mansion on the brow of Slieve Cruachra". Thus the poem expresses scepticism about a once sustaining nationalist vision and, implicitly, about the philosophical sustenance provided by the formulas of the aisling, as one among a range of traditional genres preserved in the cultural-nationalist canon.

As we shall see, Mangan's scepticism and qualified alienation from culture-building programmes take strikingly personal form, but they are also inflected by a species of philosophical questioning peculiar to his time and directly disruptive of Young Ireland's literary ideology. "Such scepticism concerning the worth of the ideals or internal models to which we have entrusted our hopes, their ability to bear the weight of our vulnerable belief, is chronic in perfectionism," Andrew H. Miller observes ${ }^{14}$. Theories of exemplarity, and of representative cultural heroes, themselves emerged at a time where none existed, and they were expressly designed to unite cultures already undergoing ideological and social fragmentation ${ }^{15}$. From the perspective of the cultural-nationalist dream, Mangan's poetics of diminishing faith was particularly destabilising. For his work lays bare the historical yearning that the figure of the national exemplar was designed to anneal or occlude, as well as the peculiar cultural anxieties attached to that yearning. A perfectionist crisis in Mangan inevitably leads to a crisis in cultural-nationalist perfectionism. Vulnerability of belief is far removed from the "true ecstatic spirit of the Irish muse" vaunted by the nationalist ideologue Charles Gavin Duffy ${ }^{16}$. And it is a result of a form of theoretical misgiving that the Nation deemed antithetical to a national literature, because putatively belonging to "high" (that is, belated and English) civilisation:

Differing from England as we do in almost everything in which one people can differ from another, in nothing do we differ so widely as in our literary wants. The philosophical tone of a high civilisation does not suit us; we have our history to make, and our writings must help to make it. We want strength, earnestness, passion, the song and the ballad, all that fires and nerves the minds of men ${ }^{17}$.

Mangan's writing on heroic nationalism is not only ideologically unstable, it is unsuitable (even "un-Irish") in revealing the distinguishing psychological features of Victorian perfectionism, in representing perfectionist hope at its most attenuated. 
course, much of Mangan's angular relationship to national perfectionism can be explained by his sense of cultural difference from the largely bourgeois institution from which it sprang. By the 1840s the poet was living in penury. However, even in the decade prior to this Mangan's movement between the high and low worlds of Dublin publishing and the Dublin back street, respectively, made for a pronounced personal anxiety about his ability adopt the role of national poet and social mentor. A cultural barrier also prohibits conscientious possession of or identification with the Irish nationalist poetic that he recites, and thus with the idealised nation that it normatively represents. Unsurprisingly, the same obstacle elucidates many of Mangan's characteristic themes and poetic mannerisms or forms. Themes of discomfort, exposure, alienation, and loss, for instance, seem deliberately to figure a sense of dislocation from the national culturebuilding enterprise. Forms of fragmentation and inarticulacy in Mangan produce an aesthetic of self-doubt and ideological disillusionment, which stems principally from his experience of social alienation.

In Andrew H. Miller's extensive studies of Victorian perfectionism, both the original desire for perfection, and the uncertain self-esteem that comes from evaluating oneself against cultural exemplars, "forces an uneasy sensitivity to exposure"- exposure to oneself and to one's audience ${ }^{18}$. In Mangan, such sensations are multiply felt, and thematised in relation to two main tropes: pained and / or guilty memory; feelings of disease and unworthiness. His texts constantly betray these to be intermingled with the sense of "exposure" and "inarticulacy" thematised in Victorian perfectionist discourse ${ }^{19}$. Thus his canon registers combinations of self-abasement and guilt before the exemplary model of the public national poet.

In the 1837 "My Adieu to the Muse" Mangan's search for "nobleness and truth" is stimulated by perfectionist models but offset by his experience of private pain. Hence "the reveil-call which on Fame's drum Time's / Hands beat for some lost hero of the Past" is offset by self-hate and self-defeat - "all the javelin memories that pierce me now". Humility before his "Father-land", in his capacity as a poet, is mingled with a desire for some vague forgiveness by it:

I owe

Ye much, and would not seem ungrateful now;

And if the laurel decorate my brow,

Be that set-off against so much woe

As Man's applause hath power to mitigate.

Such feelings do not dissipate with time. The posthumously published "The Nameless One" (1849) reiterates the theme. It expressly represses both the poet's name and detail of his personal history, while openly grieving for having endured "what future Story / will never know", and it begs his public to guard a kind memory of him in spite of his failings.

19 Elsewhere irony softens the blow of reality and undercuts the force of exemplary paradigms. "Twenty Golden Years Ago" (1840) evokes the speaker's "grand Byronian soul" in its state of "anticlimax", or depressed pastness. Thus it erodes the speaker's character as an exemplary poet type with self-deprecating irony. Such irony takes the form of parodic self-exposure in "Andrew Magrath's Reply to John O'Tuomy" (1849), which jokingly restates the unstable relations between the public poet and his private moods of pessimism and deceit: "Old Bards never vainly shall woo me, / But your tricks and your capers O'Tuomy, / Have nought in them winning - / You jest and keep grinning, 
/ But your thoughts are all guileful and gloomy". Verbal irony is the product of skepticism ; scepticism is itself impossible, however, except in relation to disappointed or disrupted idealism. Romantic ideals still played a strong part in Mangan's notion of the model poet, and these texts suggest that he felt some degree of fraudulence in his capacity to satisfy the bardic standard ${ }^{20}$.

Again, this internal conflict is characteristic of the consciousness of a poet in uneasy relation to the lower and middle-class cultures in which he doubly moved. As we shall see, when not breaking out in laughing skepticism, the Irish poetry is "wounded" by moments of voicelessness and self-doubt. Ideological disjunction and perfectionist anguish - intellectual alienation and feelings of social exclusion - thus mean that inarticulacy becomes a dominant formal feature of Mangan's verse. It is to this point I now turn.

\section{Ruin and Wound: Dialogues in Responsibility and Inarticulacy}

21 Figures and forms of silence in Mangan mark out an awkward presence in the romantic canon, at once opening onto and foreclosing upon strikingly nationalist sentiments of cultural ruin. In concluding, I want to examine how tropes of piercing and wounding, associated with personal and perfectionist crisis in Mangan, can be located in the cultural-nationalist poetics of the Famine years. Linked to this is the question of how forms of piercing - gasps, silences, moments of breathlessness and unspeakability coincide with patterns of representation in Famine writing, ambiguously functioning as a synecdoche of national history, but also of the cultural-nationalist enterprise on the point of its collapse.

Romantic ideologues valorised ruins on the Irish landscape as a visible sign of a lost cultural order. Emotional focal points, they were sites of remembrance that substituted for memory of a distant Gaelic past ${ }^{21}$. Analogous to the ruin on the landscape is the scar or wound on the human body, a visible remnant of former suffering and a figure for emotional trauma. Luke Gibbons has demonstrated that, in the literary and visual culture of late-eighteenth and nineteenth-century Ireland, the wounded body functions as a type or substitute national narrative ${ }^{22}$. The wounded subject reconnects to a violent and violating colonial history at a political-allegorical level; indeed, in Gibbon's post-colonial calculus, allegory is the grammatical type of the "semantic wound ${ }^{23}$ ".

Ruins are everywhere in Mangan's poetry and, formally, they betray their affinity to the memorialising paradigms of cultural-nationalist narrative. In "Teach Molaga" and "Kilcash" (both 1849), the abbey and castle ruins are sites where mourning for national culture occurs. In "O'Hussey's Ode", acts of political ruin are guarded in remembrance to inspire politically: "memory of the lime-white mansions" Hugh Maguire "hath laid / In ashes warms the hero's heart!" Nonetheless, it is truer to say that scars in Mangan are more commonly found on mental than physical geographies. The "arrowy, speary, sleet" that "Pierceth to the very bone" in "O'Hussey", though referable to the poem's dramatic context, in fact crystallises the ode's pained if ecstatic temper. In a parallel spirit, in the "Lamentation for Maurice FitzGerald" (1846) the mourner's "keen" is "piercing" emotion, sensation, and song mingle in the national context, but they meet in the air, not on the ground. In the poetry images of piercing, wounding, and stabbing are figurative 
vehicles for emotional pain used to intensify key emotional states that Mangan typically fails to excavate. These openings are vacant spaces that typically evacuate any meaning they moodily evoke. Resisting explication, they equally defy attachment to philosophicalhistorical narrative whether of a perfectionist or nationalist kind.

In "Farewell to the Maig" (1847), the exiled poet, "Without help, without hope, without friends, without treasure, / And thorough-pierced with arrows from Fate's laden quiver" is conveyed to be utterly "lost," "lone," "[pining]", and "[dying]". His isolation is utter. As "My Adieu to the Muse" showed, the "arrows" of "Fate" in Mangan are commonly associated with the sting of guilty memory. Accordingly such figures point up the poet's peculiar moral solipsism, an existential crisis which triggers his isolation from nation and society. In "Siberia" (1846) Mangan makes wounded seclusion into a mannered aesthetic:

In Siberia's wastes

The Ice-wind's breath

Woundeth like toothèd steel.

The use of the stiletto capital and cutting hyphen in "Ice-wind", and the sharp backward glance of the accented e in "toothèd steel", effect a visible incision on the page that mimics the scars on the speaker's mind. Meanwhile, the typological presentation of the text, the wide blank spaces against which the stanzas press, enforce the impression of claustrophobic, solitary emptiness. Particularly in emotional contexts, Mangan is slow to grant authority to the word. Thus his writing can appear peculiarly non-communicative. When psychological pain infects his nationalist poetics, therefore, it patently deflects them from their ostensible ideological goal; the labouring emotion rather appears to evoke a radically other narrative beside its nationalist shadow ${ }^{24}$.

of considerable interest is the peculiar gasping, rasping, breathlessness which enters the poems of 1846 . These poems strike up profoundly nationalist themes, in the first years of the Great Famine. Indeed, it is tempting to read in their suffocating breath some sensible evocation of the intensely sultry weather that had spread across the country with the Famine. Some are poems of national fervour, others of national failure; all ostensibly connect to the public space; yet their emotions are so synthetically devised as to persist in suggesting remoteness from the real.

Mangan's "Pulse of the Bards", a version of O'Toumy, speaks out on the subject of bardic inarticulateness, itself the result of social and political impasse in native culture. Here silence coincides with political decay, political decay with spiritual bondage:

Poets are no more, ... and Storyists are mute.

Nought is ever heard ... through tale, or lay, or lute

of the Youth of the old kingly line.

Oh! For Erin, for Erin, my spirit lies in bondage long!

's self-consciously literary response to social stasis and bardic silence is built into the poem's structure. The pulse of the bard, rendered as an ellipsis - “..." -, mimics the inarticulate gasp of Poets and Storyists as the text's rhythmic pulse.

Similar gasping breathlessness is found in the aisling "Shane Bwee; or, the Captivity of the Gaels" (1846) which knits the poet's sadness to general social declension:

Sunk in sadness, ... I darkly pondered

All the wrongs our ... lost land endures.

It is found again in "A Cry for Ireland" (1846): 
Oh, my land! ... oh, my love!

What a woe, ... and how deep,

Is thy death to my long-mourning soul!

31 Pausing declensions such as these are consonant with Mangan's tendency to deploy forms that enact the subjective experience of blocked desire; all figure a context where social and economic progress has deliberately been arrested. In their very self-consciousness, they doubtless illustrate an ironic use of form unsuited to a poetics that openly seeks to communicate national sentiment to its readership - though, again, the empty moans of these texts do appear to turn into literal phrasing in "Teach Molaga" (1846). There the poet wanders out along upon a "funereal" and "billow-beaten shore": "While in low tones, with many a pause between, / The mournful night-wind wailed". When finally legible, the pausing moan is shown to signify absence in plural directions: the death of patriot history as the source of inspiration and the death, in the present moment, of the dull promise of a nationalist future. Mangan's national poetics in the Famine years are characterised by formal evasion, therefore, and philosophical betrayal.

The romantic-national consciousness succeeds through the operation of saving analogy; likenesses breed universals, and the universal transcends the particular world. Ideally, by attaching oneself to the universal one saves oneself; transcending oneself, one leaves national history to join with nationalist myth ${ }^{25}$. However, Mangan refuses to merge with this mythic national consciousness. Instead he skirts it, as echo, shade, or perversion, or else operates as a ruined presence within it. His aesthetics of wounding, loss, and impasse inject scepticism into the conceptual framework of bardic poetry at the very level of sentence. Such analogy as emerges is not with myth, but with no-myth; not with transcendence, but with immanent failure and social crisis. It is a formula that marks the tentative emergence of another national poetic, anti-idealist in spirit, and in tune with Famine history.

The Great Famine of 1845-49 did not just implicate the ruin of the population or the national economy; it also bankrupted the cultural-nationalist dream of spiritual cohesion. The political and economic consequences of the Famine (not to speak of Famine mortality) showed up the naked differences between diverse human communities in Ireland. Making social distinction vital and vivid, the Famine produced at once more radical forms of political nationalism and more extreme forms of cultural despair. Clearly, all were antithetical to the unifying, perfectionist grammar of national culturebuilding. Famine history beggared the romantic consciousness before historical fact; and in consequence the late 1840s saw the "evaporation" of the idealist ethos that characterised Davisite cultural nationalism ${ }^{26}$.

Historical awareness, writes Octavio Paz, is coincident with "the knowledge of death". Where such consciousness enters romantic aesthetics, it corrupts both its characteristic idealism and its poetic poise, leading to a "breaking away from analogy through irony or anguish ${ }^{27 "}$. Gaps, gasps, and lacunae in Mangan - whether conceived as formal irony or anguished wail - constitute what Paz would call the "disintegrating word", a sign of this philosophical breakage. They entail a falling away from the normative philosophical order of romantic nationalism, in a manner that co-implicates the norm and the fall. Mangan's breached aesthetic, then, figures a vision of cultural perfection punctured by the particular floundering emotion of Famine history. The poetry evokes an understanding of discourse's powerlessness to effect cultural progress, as Mangan uses poetic form to explore the individual experience of futility in the face of history. 

Young-Ireland idealism, and is itself the result of his experience of social disempowerment ${ }^{28}$. What Mangan's Famine poetry produces is nationalist void. Emerging forcefully in the writing is both the poet's want of an object of hope, an explicating narrative, or some saving solidarity - as well as his material faithlessness in them. Hence in the poems of the late forties there is a tentatively romantic seeking for some larger correspondence in varieties of the historical particular. From the destruction of Pompeii, Mangan turns to the Albanian war of independence from Turkey, where scenes of distant devastation and famine evoke the local. His seeking takes curiously agitated forms. "The Song of the Albanian" (1847) is apocalyptic and calls down eschatological violence:

Gaunt Famine rideth in the van,

And Pestilence, with myriad arrows,

Followeth in fiery guise: they spare

Nor Woman, Child, nor Man!

The stricken Dead lie without barrows

By roadsides, black and bare!

Down on the burnt-up cottage roofs

The sick sun all the long day flashes. produced, "full of awful feeling of impending doom," were more "dreadful" than "any even Ireland has ever passed through" 29 ". In "Pompeii" (1847) the speaker "rave[s]", while turning through forms of "Conjectural Dread" he imagines swept over the lost city. The conjectural dread is consonant with Mangan's attachment to a poetry of outermost mood. Where high emotion ascends it is hysterical and apocalyptic. His famous "Dark Rosaleen" (1846) presents a contemporary apocalyptical vision in a characteristically personal manner. The gasp and gap mimic the passionate intensity of the speaker's state of mind; and his fevered apostrophe to "Rosaleen", the allegorical figure of Irish nationalism, shows the limits to which Mangan takes the cultural-nationalist dream:

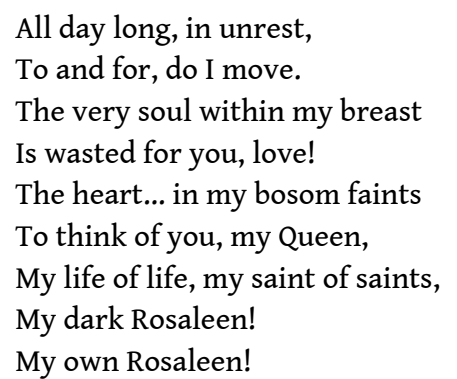

John Mitchel would subsequently try to recuperate Mangan for the nationalist tradition, merging the poet's ruin with Ireland's ${ }^{30}$. Where his apocalyptic strains become knit with 
nationalist figures and themes, the result can, indeed, be extraordinarily powerful, in spite of the disorienting influence of Mangan's iconoclasm. However, such panting agitation as is found here is temperamentally agnostic to the cultural-nationalist canon: its very emotional excess destabilises the cultural authority upon which habitual bardic verse, and thus nationalist ideology, depend. Faith, so voiced, and in a context that endangers its eclipse, forces the questioning of nationalist sentiment and aspiration. Itself beyond even the discipline of doubt, "Rosaleen's" clipped, ritual phrases rather evidence desperation for a cause-any cause-to absorb the otherwise unreckonable longing. What truly distinguishes the poem, however, is the image of the national poet that it presents, for the speaker of "Dark Rosaleen" is a craven nationalist exemplar. Neither properly present nor transcendent, he is simply beside himself.

\section{Conclusion}

While attracted to Young Ireland's idealist ethos, Mangan's marginal social status meant that his faith in a future perfected culture was always short-lived and frequently ironised, interrupted, or undermined. Such ideological irregularity on his part is consonant with his position on the periphery of romantic-nationalist circles in which he also, erratically, assisted. The texts studied in this paper illustrate the problems that both Mangan's darkening idealism and enlivening scepticism posed to heroic song in bourgeois culturebuilding. The darker existential moments in Mangan fit unevenly in a canon they also intensify, his cynical flashes render cultural nationalism uneven by exaggerating its ideals and goals. He takes things too far. Yet while his irresolution and emotional excess evidently problematise Mangan's ability to fulfil the role of exemplary national poet, he stands inside romantic nationalism sufficiently to be able to take cultural-nationalist aspiration to an anticlimax. Reading Mangan in light of the foundational tradition of nationalist perfectionism, heroic exemplarity, and girding patriotism therefore allows us to reconceptualise the later-nationalist poems as (often penetrating) excurses into the failure of cultural-nationalist idealism.

\section{NOTES}

1. Joep Leerssen, Remembrance and Imagination: Patterns in the Historical and Literary Representation of Ireland in the Nineteenth Century, Cork, Cork University Press, 1996, p. 4.

2. Seamus Deane, (ed.), "Poetry and Song, 1800-1890", The Field Day Anthology of Irish Writing, Vol. 2, Derry, Field Day, 1991, p.1-9, p. 3.

3. Quoted in Matthew Campbell, "Poetry in English, 1830-1890: From Catholic Emancipation to the Fall of Parnell", Margaret Kelleher and Philip O'Leary (eds.), The Cambridge History of Irish Literature, Vol. I, Cambridge, Cambridge University Press, 2006, p. 500-54, p. 515. 
4. David Lloyd, Nationalism and Minor Literature: James Clarence Mangan and the Emergence of Irish Cultural Nationalism, London and Berkeley, University of California Press, 1987, p. xi.

5. Seán Ryder, "Introduction", Ryder, S. (ed.); James Clarence Mangan: Selected Writings, Dublin, Dublin University Press, 2004, p. 1-13, p.8; Richard Haslam, "Broad Farce and Thrilling Tragedy': Mangan's Fiction and Irish Gothic”, Éire-Ireland, 41: 3\&4, Fall/Winter, 2006, p. 215-244; Christopher Morash, Writing the Irish Famine, Oxford, Oxford University Press, 1995, p. 122-24.

6. Patricia Coughlan, “'Fold over Fold, Inveterately Convolv'd': Some Aspects of Mangan's Intertextuality", Birgit Bamsbäck and Martin Croghan (eds.), Anglo-Irish and Irish Literature: Aspects of Language and Culture, Proceedings of the Ninth International Congress of the International Association for the Study of Anglo-Irish Literature, Held at Uppsala University, 4-7 August, 1986, Vol. 2, Studia Anglistica, University Presspsala, 1988, p. 191-200, p. 195, p. 191. Further, Matthew Campbell points to Mangan's affinities with Keats, Browning, and Tennyson, and concludes that his poetry stands confidently (and sometimes reprovingly) within late-romantic and Victorian verse cultures. See “Lyrical Unions: Mangan, O'Hussey and Ferguson", Irish Studies Review 8:3, Dec. 2000, p. 325-338, p.327.

7. Ciara Hogan, "Cultural Nationalism and the 'Cashless Bard': Class and Nation in the Poetry of James Clarence Mangan", Olivier Coquelin, Patrick Galliou, and Thierry Robin, (eds.), Political Ideology in Ireland: From the Enlightenment to the Present, Newcastle, Cambridge Scholars Press, 2009, p. 82-102.

8. S. Ryder, op. cit., p. 6.

9. All quotations from Mangan's poetry are taken from Jacques Chuto et al. (eds.), The Collected Works of James Clarence Mangan, 6 vols, Dublin and Portland, Or., Irish Academic Press, 1996-2002.

10. John Kilroy (ed.), The Autobiography of James Clarence Mangan, Dublin, Dolmen, 1969, p. 8.

11. For studies of the exemplar in the historical development of cultural identity see A. Dwight Culler, The Victorian Mirror of History, New Haven, Yale University Press, 1985, p. 20-73. See also the following works by Andrew H. Miller, which have been a central influence on this study: "Reading Thoughts: Victorian Perfectionism and the Display of Thinking", Studies in the Literary Imagination, 35:2, Fall 2002, p. 79-98; "John Henry Newman, Knowingness, and Victorian Perfectionism", Texas Studies in Literature and Language, 45:1, Spring 2003, p. 92-113; "Bruising, Laceration, and Lifelong Maiming; Or, How We Encourage Research”, ELH 70:1, Spring 2003, p. 301-318.

12. The title of Davis's seminal collection of nationalist verse. See Thomas Osborne Davis (ed.), The Spirit of the Nation. Ballads and Songs by the Writers of "The Nation", With Original and Ancient Music, Arranged for the Voice and Piano Forte, Dublin, J. Duffy, 1845.

13. Robert Welsh, Irish Poetry from Moore to Yeats, Gerrards Cross, Colin Smythe, 1980, p. 96.

14. Andrew H. Miller, “Bruising”, op. cit., p. 310.

15. James Chandler notes that Emerson, Mill, and Carlyle developed their theories of representative men in an age where none existed and in a culture characterised by their absence. See England in 1819: The Politics of Literary Culture and the Case of Romantic Historicism, Chicago, University of Chicago Press, 1998, p. 176. 
16. The quotation is from Duffy's "Introduction to the Fifth Edition", Charles Gavin Duffy (ed.), The Ballad Poetry of Ireland, $5^{\text {th }}$ rev. ed., Dublin, 1845, p. xi-xlvii, p. xiii.

17. Anon, "Current English Poets: No. 1 Alfred Tennyson and E. B. Browning", The Nation, 15 Feb. 1845, p. 314.

18. Andrew H. Miller, "Bruising", op. cit., p. 310.

19. Andrew H. Miller, “Newman”, op. cit., p. 92.

20. While it is not within the parameters of this study to address Mangan's character as a translator per se, a similar strain is felt when he seeks to present himself to his readership in the capacity of public poet/literary translator. The use of pseudonyms such as Selber (or self) and Clarence, for instance, show Mangan evading exposure for insufficient literary authority through parodic self-exposure - hence too his tendency to undermine the concept of literary authority itself. His comment that his writing was "the antithesis of plagiarism" clearly mocks up the charge of authorial irresponsibility he consciously felt at some level. (Quoted in D.J. Donoghue, The Life and Times of James Clarence Mangan, Dublin, Patrick Geddes, 1897, p. 19. Mangan refers to a writing practice he adopted, fabricating imaginary poets and poems, which then he claimed to "translate" for his readers' improvement and culture.)

21. Although she does not locate her discussion in a single chapter, Katie Trumpener's Bardic Nationalism offers a fairly comprehensive discussion of the role of ruins in romantic-national contexts. See, for example, Bardic Nationalism: The Romantic Novel and the British Empire, Princeton, Princeton University Press, 1997, p. 69-70; 82-84; 102-04; 123-24; 143-45.

22. Luke Gibbons, Edmund Burke and Ireland: Aesthetics, Politics and the Colonial Sublime, Cambridge, Cambridge University Press, 2003, p. 39-82.

23. Ibid., p. 77.

24. This tendency has caused readers to judge Mangan's poetic as selfish, not social or national. Ellen Shannon-Mangan finds that Mangan exploited the Famine to develop themes of "personal dissolution", James Clarence Mangan: A Biography, Dublin and Portland, Or: Irish Academic P, 1996, p. 206. See also Jacques Chuto's comments on the ambiguous "nationalism" of Mangan's Famine verse, "Rhétorique et Authenticité chez J.C. Mangan", unpublished conference paper delivered to the Congrès S.A.E.S. (Tours, 1977), cited in D. Lloyd, "Great Gaps in Irish Song: James Clarence Mangan and the Ideology of the Nationalist Ballad", Irish University Review, 14, Autumn 1984, p. 182-83.

25. My discussion of nationalist myth here is influenced by Richard Kearney's analysis of "utopian myth" in Postnationalist Ireland: Politics, Culture, Philosophy, London, Routledge, 1997, p. 122-124.

26. Seamus Deane, "The Famine and Young Ireland", Field Day Anthology, op. cit. p. 115-20, p. 117.

27. Octavio Paz, Children of the Mire: Modern Poetry from Romanticism to the Avant-Garde, trans. Rachel Phillips, London and Cambridge, MA., Harvard University Press, 1974, p. 57.

28. Christopher Morash places Mangan's Famine writing beside that of a generation of working-class poets such as Francis Davis, John de Jean Frazer, and John Keegan, all of whom work in forms of apocalyptic verse, a poetry of impasse and disintegration, to voice proletarian disaffect with from bourgeois nationalism. See Christopher Morash, op. cit., p. 122-24. It is an index of the general weakness of class politics and poetics in mid-century 
Ireland that this protesting consciousness ultimately finds no stable vocabulary or ideological resting ground. Crucial to Mangan's rehearsal of poetic futility in the face of historical crisis, for instance, is an often frenzied longing for the forms and philosophies he undermines.

29. Martin MacDermott, (ed.), The New Spirit of the Nation: or, Ballads and Songs by the Writers of "The Nation," Containing Songs and Ballads Published Since 1845, $2^{\text {nd }}$ ed., Dublin, T. Fisher Unwin, 1896, p. XXII.

30. "His history and fate were indeed a type and shadow of the land he loved so well". John Mitchel, "Biographical Introduction", Poems by James Clarence Mangan, New York, P. M. Laverty, 1859. p. 7-31, p. 15.

\section{ABSTRACTS}

Uneasy assimilation to bourgeois nationalism and a qualified alienation from it are the crucial defining characteristics of Mangan's essentially subaltern poetic, explaining its frequent moments of cynicism, vacillation, and ideological disjunction. This essay explores Mangan's engagement with a literature of cultural improvement, national perfectionism, and bardic exemplarity, to find that the same exercise throws up metaphors of wound, ruin, and rupture, which record his simultaneous dislocation from cultural-nationalist idealism. Mangan evokes a nationalist canon he evades, and corrupts the nationalism he evokes.

La poésie de Mangan est doublement caractérisée par une assimilation inconfortable au nationalisme bourgeois ainsi qu'à un détachement mitigé vis-à-vis de ce même nationalisme, ce qui explique ses fréquents moments de cynisme, ses hésitations, et sa distance vis-à-vis de l'idéologie. Le présent essai examine l'engagement de Mangan dans une littérature soucieuse d'amélioration culturelle, de perfectionnisme national et d'exemplarité bardique, pour découvrir que cette pratique fait émerger des métaphores liées à la blessure, la ruine et la rupture, qui témoignent de sa désaffiliation à l'égard de l'idéalisme culturel et nationaliste. Mangan évoque un idéal nationaliste dont il se soustrait et corrompt le nationalisme qu'il évoque.

\section{INDEX}

Mots-clés: poésie, nationalisme culturel, Mangan James Clarence, rôle social de l'artiste

Keywords: poetry, cultural nationalism, social role of the artist

\section{AUTHOR}

CIARA HOGAN

Université Paris Descartes 